\title{
A Preliminary Study: Why Develop High Order Thinking Skills Worksheets Based on the 3N
}

\author{
Fitria Sulistyowati ${ }^{*}$, Esti Harini ${ }^{2}$ \\ ${ }^{1,2}$ Universitas Sarjanawiyata Tamansiswa \\ *fitria.sulistyowati@ustjogja.ac.id
}

Received: December 2020; Accepted: December 2020; Published: January 2021

\begin{abstract}
This qualitative research is a preliminary study of a 4-D model development research that aims to describe the basic problems, student characteristics, the formulation of learning outcomes, and specific learning goals as the initial stage of developing a high order thinking skills (HOTS) exercise bank based on $3 N$ in Algebra. Research subjects at the analysis stage of student characteristics are all students taking Algebra courses in Mathematics Education Department Universitas Sarjanawiyata Tamansiswa for the 2019/2020 academic year. Data were collected using a literature study, observation, documentation. The data obtained were analyzed descriptively with the following steps: (1) preparing the data, (2) data coding, (3) searching for findings, (4) constructing the framework, and interpreting the data. The results of this study are: (1) Algebra learning centered on lecturers and students has difficulty solving non-routine problems, (2) there are only 1.59\% of students who implemented to check the correctness of solutions in solving HOTS problems, (3) CPMK Algebra, and (4) formulation of specific learning goals. These results are used as a reference in the design stage of exercise bank development.

Keywords: high order thinking, exercise bank, problem-solving.
\end{abstract}

How to Cite: Sulistyowati, F. \& Harini, E. (2021). A Preliminary Study: Why Develop High Order Thinking Skills Worksheets Based on the 3N. Journal of Medives: Journal of Mathematics Education IKIP Veteran Semarang, 5(1), 105-117. 


\section{PENDAHULUAN}

Proses pembelajaran memiliki peranan penting dalam meningkatkan sumber daya manusia di Indonesia (Sunarsi, 2018). Proses pembelajaran yang dilaksanakan pada pendidikan tinggi harus diselenggarakan secara kolaboratif yaitu capaian pembelajaran lulusan diraih melalui proses pembelajaran bersama yang melibatkan interaksi antar individu pembelajar untuk menghasilkan sikap, pengetahuan, dan keterampilan (Permenristekdikti No, 44 C.E.). Tiga kemampuan tersebut diperoleh melalui proses berpikir mengamati, menanya, mencoba, menalar, menyaji, mencipta (Permendikbud No, 21 C.E.). Menalar, menyaji, dan mencipta dari proses berpikir merupakan kemampuan High Order Thinking (HOT) (Gunawan \& Palupi, 2016; Sulistyowati et al., 2019). Oleh karena itu, mahasiswa perlu memiliki kemampuan HOT sebagai upaya peningkatan sumber saya manusia di Indonesia.

Permasalahannya adalah tidak semua mahasiswa pendidikan matematika terbiasa berpikir tingkat tinggi, bahkan rata-rata memiliki kemampuan berpikir yang cenderung rendah dan sedang (Mairing, 2018; Nuriyatin \& Widadah, 2018). Hal ini mengakibatkan mahasiswa kesulitan ketika menyelesaikan permasalahan yang membutuhkan kegiatan menalar atau menyaji atau mencipta. Sebagai contoh diberikan permasalahan pada Gambar 1.

Permasalahan HOT pada Gambar

1 dapat diselesaikan dalam beberapa versi, di antaranya menggunakan: (1) konsep perbandingan senilai, dan (2) penalaran logis. Jika dikerjakan
Untuk membuat dua gelas jus jeruk, diperlukan lima buah jeruk segar. Berapa buah jeruk segar yang harus disediakan untuk membuat lima gelas jus jeruk?

Gambar 1. Contoh permasalahan HOT

menggunakan aturan perbandingan senilai, maka buah jeruk segar yang harus disediakan sebanyak 12,5 buah, Secara matematis hal ini tidak ada salahnya, tetapi secara kontekstual hal ini kurang tepat karena tentunya tidak ada buah jeruk yang merupakan setengah dari buah jeruk lainnya. Oleh karena itu, penalaran logis dibutuhkan untuk menyelesaikan permasalahan pada Gambar 1 dengan tepat, yaitu minimal diperlukan 13 buah jeruk untuk membuat lima gelas jus jeruk.

Penyelesaian permasalahan pada Gambar 1 menggunakan aturan perbandingan senilai tanpa menarik kesimpulan baru bahwa dibutuhkan minimal 13 buah jeruk, mengindikasikan kegiatan penyelesaian yang rutin dan terpusat pada bagaimana mengerjakan atau menemukan jawaban (Mahdayani, 2016; Pasandaran, 2019). Di sisi lain, penyelesaian permasalahan tanpa adanya kegiatan penarikan kesimpulan menunjukkan tidak ada kegiatan penalaran (Hendriana \& Soemarmo, 2014). Berdasarkan hal tersebut, terdapat permasalahan utama, yaitu: (1) penyelesaian masalah menggunakan cara rutin dan terpusat pada bagaimana mengerjakan atau menemukan jawaban, (2) kurangnya penalaran dalam penyelesaian masalah. Latihan soal yang tidak rutin dapat dijadikan solusi pada permasalahan pertama, sedangkan solusi 
permasalahan kedua dapat diatasi menggunakan metode pembelajaran yang mampu memberikan kegiatan penalaran.

\section{Bank soal High Order Thinking} Skills (HOTS) berbasis Nitèni, Nirokké, Nambahi (3N) merupakan salah satu inovasi baru dalam perkuliahan Aljabar yang dapat mengatasi beberapa permasalahan tersebut. Hal ini dikarenakan soal-soal HOTS mengukur kemampuan: (1) transfer satu konsep ke konsep lainnya, (2) memproses dan menerapkan informasi, (3) mencari kaitan dari berbagai informasi yang berbedabeda, (4) menggunakan informasi untuk menyelesaikan masalah, dan (5) menelaah ide dan informasi secara kritis (Dr. I Wayan Widana, S.Pd., 2017). Selain itu, $3 \mathrm{~N}$ adalah salah satu ajaran Ki Hadjar Dewantara yang memberikan kegiatan: (1) secara cermat mengenali, dan menangkap makna (sifat, ciri, prosedur, kebenaran) dari suatu objek amatan, dengan cara memperhatikan, membanding-bandingkan, mengamati secara seksama, jeli dan mendalam serta melibatkan seluruh indra (Nitèni), (2) menirukan bagaimana mengolah permasalahan menjadi karya yang baik, yang mudah dicerna dan dipahami menggunakan bahasa sendiri (Nirokké), (3) merancangan dan menyempurnakan, sehingga menjadikan pengalaman estetis dengan perwujudan suatu temuan, atau kemungkinan-kemungkinan atau sebuah makna kebaruan (Nambahi) (Ipung Kurniawan Yunianto, 2014).

Beberapa uraian sebelumnya, mengindikasikan bahwa pengembangan bank soal HOTS berbasis 3N merupakan salah satu inovasi baru yang dapat meningkatkan kemampuan mahasiswa dalam memecahkan permasalahan Aljabar. Oleh karena itu, perlu dilakukan studi pendahuluan sebagai langkah awal pengembangan bank soal HOTS berbasis $3 \mathrm{~N}$ dengan tujuan mendeskripsikan masalah dasar, karakteristik mahasiswa, rumusan capaian pembelajaran dan tujuan pembelajan khusus pada mata kuliah Aljabar.

\section{METODE PENELITIAN}

Penelitian kualitatif dengan analisis deskriptif ini merupakan studi pendahuluan dari penelitian pengembangan model 4-D. Tahapan dalam penelitian ini meliputi: (1) analisis awalakhir, (2) analisis karakteristik mahasiswa, (3) analisis tugas, (4) analisis konsep, (5) perumusan tujuan pembelajaran khusus (Prasetyo, 2011). Penelitian ini bertujuan untuk mendeskripsikan masalah dasar, karakteristik mahasiswa, rumusan capaian pembelajaran dan tujuan pembelajan khusus pada mata kuliah Aljabar. Subjek penelitian pada tahap analisis karakteristik mahasiswa adalah seluruh mahasiwa yang mengambil mata kuliah Aljabar di program studi Pendidikan Matematika UST pada tahun ajaran 2019/2020. Teknik pengumpulan data yang digunakan adalah studi literatur, observasi dan dokumentasi. Studi literatur bertujuan untuk mengumpulkan beberapa hasil penelitian yang relevan dengan penelitian yang akan dilakukan, kemudian mengaitkan hasil penelitian tersebut dengan permasalahan yang diperoleh pada hasil studi (Resbiantoro \& Nugraha, 2017; Yulianti et al., 2017). Selain itu, dilakukan telaah standar kompetensi, kompetensi dasar, 
konsep dan tugas yang diperoleh dari RPS maupun buku. Observasi bertujuan untuk mengetahui permasalahan yang muncul saat proses pembelajaran Aljabar. Dokumentasi bertujuan untuk mengetahui tingkatan berpikir mahasiswa pada kemampuan pemecahan masalah melalui tes tertulis. Data yang diperoleh dianalisis secara deskriptif dengan tahapan: (1) menyiapkan data yang akan dianalisis dengan melihat signifikansi atau pentingnya data yang diperoleh, (2) koding data, (3) mencari pola atau tema atau temuan yang mengikat data satu dengan lainnya, (4) mengkonstruksikan kerangka dan menafsirkannya untuk mendapatkan esensi dari data tersebut (Raco, n.d.). Hasil analisis data dijadikan acuan untuk merumuskan tujuan pembelajaran khusus yang selanjutnya akan digunakan untuk merancang draft awal bank soal yang akan dikembangkan.

\section{HASIL DAN PEMBAHASAN}

Hasil tahap pendefinisian pada penelitian ini merupakan hasil kegiatan analisis awal-akhir, karakteristik mahasiswa, tugas, konsep, dan perumusan tujuan pembelajaran khusus.

\section{Analisis Awal-Akhir}

Analisis awal-akhir bertujuan untuk memunculkan dan menetapkan masalah dasar yang dihadapi dalam pembelajaran, sehingga diperlukan suatu pengembangan bahan ajar (Thiagarajan, 1974). Analisis awal-akhir pada penelitian ini merupakan kegiatan menemukan masalah dasar pada mata kuliah Aljabar dan rasionalitas diperlukannya pengembangan Bank Soal HOTS berbasis $3 \mathrm{~N}$ sebagai salah satu solusi permasalahan tersebut. Beberapa masalah dasar yang ditemukan dalam perkuliahan Aljabar adalah: (1) proses pembelajaran masih terpusat pada dosen; (2) mahasiswa mengalami kesulitan dalam menyelesaikan permasalahan Aljabar yang berbeda dengan contoh soal yang diberikan dosen; (3) mahasiswa terfokus pada menemukan jawaban.

Proses pembelajaran yang terpusat pada dosen merupakan masalah karena tidak lebih baik daripada pembelajaran yang terpusat pada mahasiswa (Camac, 2018; Polly et al., 2014). Di sisi lain, proses pembelajaran yang dilaksanakan pada pendidikan tinggi seharusnya diselenggarakan melalui proses berpikir menggunakan pendekatan saintis atau metode ilmiah untuk menghasilkan kemampuan sikap, pengetahuan dan keterampilan yang maksimal (Permendikbud No, 21 C.E.; Permenristekdikti No, 44 C.E.; Raharjo, 2017; Sariningsih \& Kadarisma, 2016). Langkah-langkah metode ilmiah: mengamati, menanya, menalar (Nitèni), mencoba (Nirokké), dan mengomunikasikan (Nambahi) (Wahyuni, 2017). Berdasarkan uraian tersebut, kemampuan Aljabar mahasiswa khususnya sikap, pengetahuan dan keterampilan dapat maksimal, jika proses pembelajaran berpusat pada mahasiswa dan melibatkan kegiatan Nitèni, Nirokké, Nambahi.

Mahasiswa kesulitan dalam menyelesaikan permasalahan Aljabar yang berbeda dengan contoh soal yang diberikan dosen dan terfokus menemukan jawaban, dikatakan sebagai masalah karena mengindikasikan tidak adanya pembiasaan menyelesaikan permasalah- 
an yang tidak rutin (Mahdayani, 2016; Pasandaran, 2019). Hal ini diperkuat dengan hasil pekerjaan salah satu mahasiswa ketika menyelesaikan permasalahan Aljabar yang dapat dilihat pada Gambar 2.

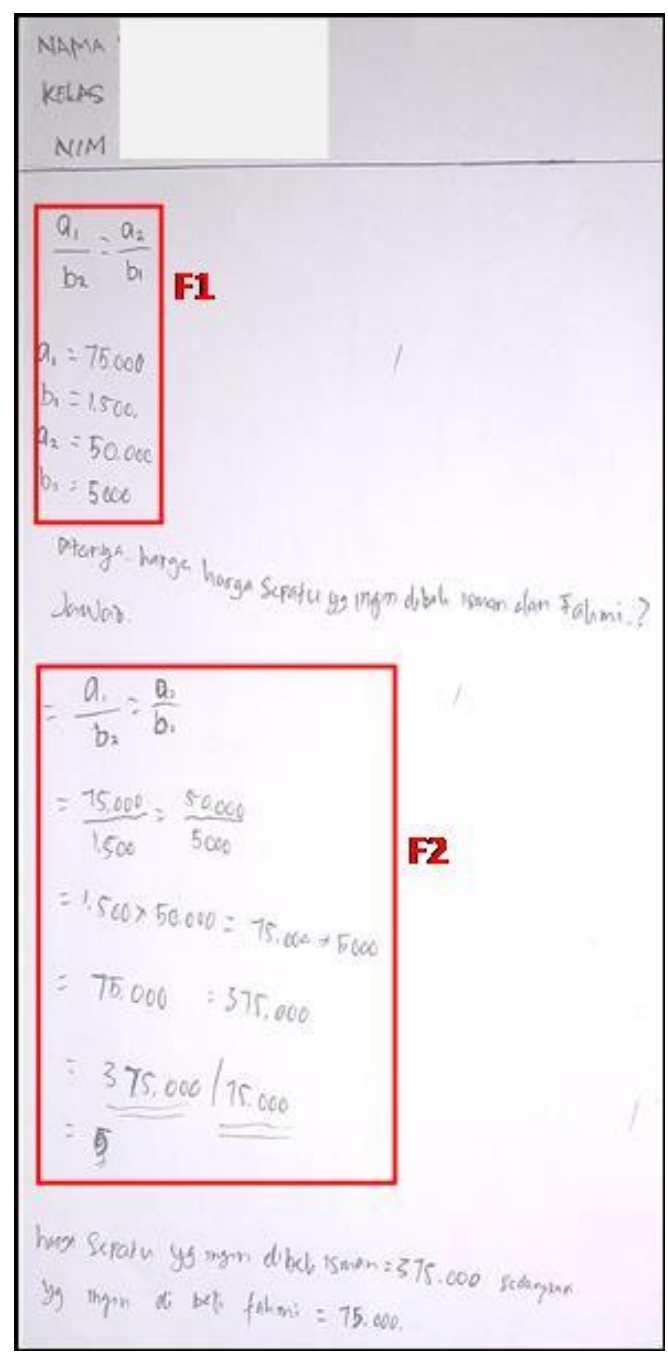

Gambar 2. Hasil Pekerjaan Mahasiswa dalam Menyelesaikan Permasalahan Aljabar

Pada Gambar 2, diperoleh temuan F1 dan F2. F1 mengindikasikan mahasiswa hanya meniru contoh pengerjaan yang dilakukan dosen karena pada kegiatan sebelumnya dosen memberikan contoh soal terkait perbandingan. Sementara F2 mengindikasikan bahwa mahasiswa terpusat pada menghitung dan tidak memahami tujuan perhitungan meskipun pada langkah sebelumnya sudah tersurat. Temuan F1 dan F2 memberikan gambaran bahwa mahasiswa belum mampu menyelesaikan permasalahan yang berbeda dengan contoh dari dosen dan mahasiswa terfokus menemukan jawaban melalui perhitungan yang kurang jelas tujuannya. Hal ini mengakibatkan alur pengerjaan menjadi tidak terstruktur sehingga permasalahan tidak dapat diselesaikan dengan tepat. Di sisi lain, kemahiran memilih strategi pada pemecahan masalah non-rutin dipengaruhi kemampuan menalar, menyaji, dan mencipta (Conklin, 2011; Gunawan \& Palupi, 2016; Sulistyowati et al., 2019). Selain itu, soal HOTS memberikan efek potensial yang baik terhadap kemampuan berpikir tingkat tinggi siswa (Nailul, 2018). Hal ini berarti bahwa dalam perkuliahan Aljabar, mahasiswa harus terbiasa menyelesaikan soal HOTS yang sudah jelas memberikan efek potensial baik terhadap kemampuan HOT sehingga mahasiswa mahir memilih strategi dalam pemecahan masalah non-rutin. Pada akhirnya, mahasiswa tidak lagi mengalami kesulitan jika diberikan permasalahan Aljabar yang berbeda dengan contoh soal yang diberikan dosen.

\section{Analisis Konsep dan Tugas}

Analisis konsep dilakukan untuk mengidentifikasi konsep pokok yang akan diajarkan, menyusunnya dalam bentuk hirarki, dan merinci konsepkonsep individu ke dalam hal yang kritis dan relevan. Analisis konsep merupakan 
satu langkah penting untuk memenuhi prinsip kecukupan dalam membangun konsep atas materi-materi yang digunakan sebagai sarana pencapaian kompetensi dasar dan standar kompetensi (Thiagarajan, 1974). Analisis tugas bertujuan untuk mengidentifikasi keterampilan utama yang akan dikaji oleh peneliti dan menganalisisnya kedalam himpunan keterampilan tambahan yang mungkin diperlukan (Thiagarajan, 1974). Analisis ini memastikan ulasan yang menyeluruh tentang tugas dalam materi pembelajaran.

Analisis konsep dan tugas diperoleh melalui telaah kurikulum prodi Pendidikan Matematika UST, Standar Nasional Pendidikan Tinggi (SNDIKTI), Kerangka Kualifikasi Nasional Indonesia (KKNI) dan beberapa literatur tentang materi Aljabar. Telaah kurikulum prodi Pendidikan Matematika UST dan SN-DIKTI dimaksudkan untuk menentukan Capaian Pembelajaran Lulusan (CPL) dan Capaian Pembelajaran Mata Kuliah (CPMK) pada mata kuliah Aljabar. CPL yang diharapkan oleh pemerintah mencakup unsur sikap, keterampilan umum, pengetahuan dan keterampilan khusus (Riset, n.d.). Unsur sikap dan keterampilan umum mengacu pada SN-DIKTI sebagai standar minimal, sedangkan unsur ketrampilan khusus dan pengetahuan dirumuskan dengan mengacu pada deskriptor KKNI sesuai dengan jenjang pendidikannya yang dikembangkan oleh prodi (Perpres No, 8 C.E.; Riset, n.d.). Adapun literatur yang ditelaah merupakan beberapa hasil penelitian dan buku yang berkaitan dengan materi Aljabar. Hasil dari telaah literatur tersebut kemudian disinkronkan dengan CPL dan CPMK yang diperoleh pada kegiatan sebelumnya. Hasil dari telaah kurikulum prodi Pendidikan Matematika UST, SN-DIKTI, KKNI dan beberapa literatur tentang materi Aljabar tersebut merupakan kerangka dasar konsep materi Aljabar dan tugas terstrukturnya yang akan disampaikan dalam Bank Soal.

Terdapat 10 standar minimal kemampuan sikap dan 9 standar minimal keterampilan umum (Perpres No, 8 C.E.; Riset, n.d.). Berdasarkan telaah yang telah dilakukan, CPL kemampuan sikap yang paling relevan dengan pembelajaran Aljabar adalah menunjukkan sikap bertanggungjawab atas pekerjaan di bidang keahliannya secara mandiri. CPL tersebut dipilih karena pembelajaran Aljabar dapat memunculkan kemandirian belajar yang mendorong mahasiswa untuk bertanggung jawab dalam proses belajar (Simanjuntak, n.d.; Werdiningsih, 2019). Sementara itu, CPL kemampuan keterampilan umum yang paling relevan dengan materi Aljabar adalah (1) mampu menunjukkan kinerja mandiri, bermutu, dan terukur; (2) mampu mengambil keputusan secara tepat dalam konteks penyelesaian masalah di bidang keahliannya, berdasarkan hasil analisis informasi dan data. Dua CPL tersebut dipilih, karena: (1) dalam pembelajaran Aljabar mahasiswa diberikan kesempatan untuk mandiri dalam belajar, berpikir kritis dan mengoptimalkan hasil belajar; (2) dalam pembelajaran Aljabar, dibutuhkan penalaran yang tinggi untuk menyelesaikan permasalahan (Andriani, 2015; Muhammad, 2017; Simanjuntak, n.d.; Waluyo \& Sari, 2017; Werdiningsih, 2019). 
Sesuai dengan deskriptor KKNI pada keterampilan khusus, maka mahasiswa lulusan Sarjana setidaknya memiliki kemampuan dalam mengaplikasikan, mengkaji, membuat desain, memanfaatkan IPTEKS, menyelesaikan masalah, sedangkan pada kemampuan pengetahuan mahasiswa lulusan Sarjana mampu menguasai konsep teoritis bidang pengetahuan dan keterampilan tertentu secara umum dan konsep teoritis bagian khusus dalam bidang pengetahuan dan keterampilan tersebut secara mendalam. Prodi Pendidikan Matematika UST mengembangkan deskriptor tersebut menjadi 11 capaian pembelajaran kemampuan pengetahuan dan 12 capaian pembelajaran kemampuan keterampilan khusus. Pada kemampuan pengetahuan, dipilih P1 yaitu menguasai konsep matematika yang diperlukan untuk melaksanakan pembelajaran di satuan pendidikan dasar dan menengah, sedangkan pada kemampuan keterampilan khusus dipilih CP-KK12 yaitu mampu mengaplikasikan Ajaran Tamansiswa sesuai dengan profesi dan keahlian sebagai pendidik matematika, peneliti bidang pendidikan matematika, edupreneur matematika, dan penulis pendidikan matematika. Pada kemampuan pengetahuan, CPL tersebut dipilih karena Aljabar merupakan salah satu materi pokok yang diberikan pada jenjang pendidikan dasar, menengah maupun tinggi, sehingga Aljabar perlu dikuasai oleh mahasiswa agar mampu melaksanakan pembelajaran di satuan pendidikan dasar dan menengah (Adelman, 2006; Herbert, 1984; Ma \& Wilkins, 2007; Woodward, 1980). Pada kemampuan keterampilan khusus, CPL tersebut dipilih karena UST sebagai bagian dari perguruan Tamansiswa wajib menerapkan ajaran Ki Hajar Dewantara dalam setiap kegiatan pembelajaran dalam hal ini pembelajaran Aljabar, sehingga tercipta lulusan yang mampu mengaplikasikan ajaran tersebut sesuai dengan profesi dan keahliannya. Berdasarkan uraian CPL tersebut, dirumuskan CPMK pada mata kuliah Aljabar yang dapat dilihat pada Tabel 1.

Konsep Aljabar dapat dikuasai melalui pemecahan atau penyelesaian masalah (Hendriana et al., 2017; Hendriana \& Soemarmo, 2017). Pembelajaran Aljabar dapat memunculkan kemandirian belajar yang mampu meningkatkan kemampuan mahasiswa (Sulistyowati et al., 2017; Werdiningsih, 2019). Di sisi lain, $3 \mathrm{~N}$ adalah salah satu ajaran Ki Hadjar Dewantara yang dapat diterapkan sebagai metode pembelajaran dan memberikan kegiatan bermutu dengan meliputi menalar, menyaji, mencipta (Budiati et al., 2018; Ipung Kurniawan Yunianto, 2014). Berdasarkan hal ini, dapat dikatakan bahwa penyelesaian permasalahan Aljabar menjadi salah satu cara untuk menguasai konsep Aljabar yang didukung pembelajaran mandiri dan bermutu dengan menerapkan $3 \mathrm{~N}$ sehingga kemampuan mahasiswa dapat meningkat secara optimal (CPMK1). Salah satu prosedur dalam pemecahan masalah adalah carrying out the plan yaitu kegiatan memilih strategi yang tepat dalam penyelesaian suatu masalah dengan menggunakan data-data yang telah diidentifikasi (Fan \& Zhu, 2007; Liljedahl et al., 2016). Di sisi lain, pembelajaran Aljabar dapat memuncul- 
Tabel 1. CPL dan CPMK pada Matkul Aljabar

\begin{tabular}{|c|c|c|}
\hline Kemampuan & CPL Prodi & CPMK \\
\hline Sikap & $\begin{array}{l}\text { Menunjukkan sikap bertanggungjawab atas } \\
\text { pekerjaan di bidang keahliannya secara } \\
\text { mandiri (S9) }\end{array}$ & $\begin{array}{l}\text { CPMK1. Mampu } \\
\text { menyelesaikan } \\
\text { permasalahan Aljabar }\end{array}$ \\
\hline $\begin{array}{l}\text { Pengetahuan } \\
\text { (Prodi) }\end{array}$ & $\begin{array}{l}\text { Menguasai konsep matematika yang } \\
\text { diperlukan untuk melaksanakan } \\
\text { pembelajaran di satuan pendidikan dasar dan } \\
\text { menengah (P1) }\end{array}$ & $\begin{array}{l}\text { dengan menerapkan } \\
\text { beberapa konsep Aljabar } \\
\text { dan ajaran } 3 \mathrm{~N} \text { secara } \\
\text { mandiri, bermutu dan }\end{array}$ \\
\hline $\begin{array}{l}\text { Keterampilan } \\
\text { Umum }\end{array}$ & $\begin{array}{l}\text { Mampu menunjukkan kinerja mandiri, } \\
\text { bermutu, dan terukur (KU2) } \\
\text { Mampu mengambil keputusan secara tepat } \\
\text { dalam konteks penyelesaian masalah di } \\
\text { bidang keahliannya, berdasarkan hasil } \\
\text { analisis informasi dan data (KU5) }\end{array}$ & $\begin{array}{l}\text { terukur }(\mathrm{P} 1 ; \mathrm{KU} 2 ; \mathrm{CPKK}- \\
\text { 12) } \\
\text { CPMK2. Mampu memilih } \\
\text { strategi yang tepat dalam } \\
\text { menyelesaikan } \\
\text { permasalahan Aljabar dan }\end{array}$ \\
\hline $\begin{array}{l}\text { Keterampilan } \\
\text { Khusus (Prodi) }\end{array}$ & $\begin{array}{l}\text { Mampu mengaplikasikan ajaran tamansiswa } \\
\text { sesuai dengan profesi dan keahlian sebagai } \\
\text { pendidik matematika, peneliti bidang } \\
\text { pendidikan matematika, edupreneur } \\
\text { matematika, dan penulis pendidikan } \\
\text { matematika (CP-KK12) }\end{array}$ & $\begin{array}{l}\text { dapat } \\
\text { mempertanggungjawabkan } \\
\text { hasil penerapan strategi } \\
\text { tersebut (S9;KU5) }\end{array}$ \\
\hline
\end{tabular}

kan kemandirian belajar yang mendorong mahasiswa untuk bertanggung jawab dalam proses belajar (Simanjuntak, n.d.; Werdiningsih, 2019). Berdasarkan hal ini, pemilihan strategi dalam penyelesaian masalah menjadi salah satu unsur yang mampu menunjukkan kegiatan pengambilan keputusan secara tepat berdasarkan data yang diketahui, tentunya didukung dengan pembelajaran Aljabar yang mampu memunculkan kemandirian belajar untuk mendorong sikap bertanggung jawab mahasiswa (CPMK2). CPMK tersebut menjadi salah satu tolak ukur ketercapaian pembelajaran pada Mata Kuliah Aljabar.

Selain perumusan CPMK, diperlukan analisis materi yang akan disampaikan dalam pembelajaran. Materi yang dianalisis adalah standar materi pada mata kuliah Aljabar jenjang Pendidikan tinggi (Herriott \& Dunbar,
2009; Kaufmann \& Schwitters, 2014). Materi yang terpilih, selanjutnya disesuaikan dengan CPMK dan CPL yang dibebankan pada mata kuliah Aljabar. Rumusan yang telah disusun tersebut, dirangkai dalam Rencana Pembelajaran Semester (RPS). Berdasarkan hal ini, materi Aljabar yang akan disampaikan pada Bank Soal yang dikembangkan adalah: (1) fungsi, (2) persamaan dan pertidaksamaan linier dan kuadrat, (3) eksponen dan logaritma, (4) bilangan irrasional, (5) fungsi pecah, dan (6) pola bilangan, barisan dan deret.

\section{Analisis Karakteristik Mahasiswa}

Analisis karakteristik mahasiswa merupakan telaah tentang karakteristik mahasiswa yang sesuai dengan desain pengembangan bahan ajar. Karakteristik itu meliputi latar belakang kemampuan akademik (pengetahuan), perkembangan kognitif, serta keterampilan-keteram- 
pilan individu atau sosial yang berkaitan dengan topik pembelajaran, media, format dan bahasa yang dipilih (Thiagarajan, 1974). Pada penelitian ini, karakteristik mahasiswa yang akan ditelaah merupakan kemampuan mahasiswa dalam menyelesaikan permasalahan HOTS pada pokok bahasan Aljabar.

Karakteristik mahasiswa dalam penelitian ini adalah tingkatan berpikir mahasiswa pada materi Aljabar yang mengacu pada dimensi proses berpikir Taksonomi Bloom versi AndersonKarthwohl. Langkah awal yang dilakukan adalah menyusun permasalahan HOTS yang akan diujikan kepada mahasiswa. Permasalahan HOTS terdiri dari satu butir soal tes kemampuan pemecahan masalah matematik jenjang Sekolah Menengah Atas (SMA) kelas X pada materi Sistem Persamaan Linear Tiga Variabel (SPLTV) (Utari et al., 2019). Adapun bentuk permasalahan HOTS tersebut dapat dilihat pada Gambar 2.

\section{TES KEMAMPUAN BERPIKIR TINGKAT TINGGI}

Isman ingin membeli sepatu dengan harga dua kali sepatu yang dibeli Fahmi. Fahmi telah memiliki uang $\operatorname{Rp} 75.000,00$ dan akan menabung $\mathrm{Rp} 1.500$, 00 per minggu, sementara Isman baru memiliki uang $\mathrm{Rp} 50.000,00$ dan akan menabung $\mathrm{Rp} 5.000$, 00 per minggu. Akan dihitung harga sepatu yang ingin dibeli Isman dan Fahmi masing-masing.

a. Tulislah unsur yang diketahui dan ditanyakan

b. Susun model matematika masalah dan tulis konsep matematika yang termuat dalam model tersebut

c. Rancang strategi penyelesaian masalah, dan selesaikan. Sertakan konsep atau rumus yang digunakan pada tiap langkah

d. Periksa kebenaran solusi yang diperoleh

Gambar 2. Bentuk Permasalahan HOTS pada Materi SPLTV
Tabel 2. Persentase Mahasiswa yang Menguasai Tahap Pemecahan Masalah

\begin{tabular}{lc}
\hline $\begin{array}{l}\text { Tahap Pemecahan } \\
\text { Masalah }\end{array}$ & Persentase \\
\hline $\begin{array}{l}\text { Mengidentifikasi unsur } \\
\text { yang diketahui dan } \\
\text { ditanyakan }\end{array}$ & $84,13 \%$ \\
$\begin{array}{l}\text { Menyusun model } \\
\text { matematika dan }\end{array}$ & $52,38 \%$ \\
mengidentifikasi strategi & \\
$\begin{array}{l}\text { Memilih dan melaksanakan } \\
\text { strategi yang sesuai }\end{array}$ & $50,79 \%$ \\
$\begin{array}{l}\text { Memeriksa kebenaran } \\
\text { solusi }\end{array}$ & $1,59 \%$ \\
\hline
\end{tabular}

Jika dicermati lebih lanjut, permasalahan Aljabar pada Gambar 2 memberikan kesempatan kepada mahasiswa untuk: (1) menganalisis unsurunsur yang dibutuhkan dalam menyelesaikan masalah dan menyatakannya dalam bentuk model matematika, (2) memilih strategi yang sesuai dan memeriksa kebenaran strategi tersebut. Kegiatan tersebut merupakan prosedur kognitif dalam pemecahan masalah yang meliputi: (1) Understanding the problem, (2) Devising a plan, (3) Carrying out the plan, (4) Looking back (Fan \& Zhu, 2007; Liljedahl et al., 2016). Kegiatan tersebut merupakan rangkaian menalar, menyaji dan mencipta dalam menyelesaikan permasalahan Aljabar (Conklin, 2011; Gunawan \& Palupi, 2016; Sulistyowati et al., 2019). Oleh karena itu, tes tersebut dapat dijadikan alat untuk mengukur kemampuan berpikir tingkat tinggi. Persentase hasil dari tes kemampuan berpikir tingkat tinggi mahasiswa dapat dilihat pada Tabel 2.

Pada Tabel 2 terlihat bahwa lebih dari 50\% mahasiswa telah menguasai tiga tahap pemecahan masalah. 
Permasalahannya adalah hanya ada $1,59 \%$ mahasiswa yang melaksanakan kegiatan memeriksa kebenaran solusi. Hal ini menjadi masalah, karena lemahnya kegiatan memeriksa kebenaran solusi mengakibatkan kurangnya proses mengevaluasi hasil pemecahan masalah yang telah dilakukan oleh mahasiswa sehingga kemampuan HOT tidak tercapai secara optimal (Sulistyowati et al., 2017). Hasil tersebut menunjukkan bahwa mahasiswa prodi Pendidikan Matematika UST belum sepenuhnya menguasai bagaimana memecahkan masalah Aljabar.

\section{Perumusan Tujuan Pembelajaran Khusus}

Berdasarkan analisis yang telah dilakukan, dirumuskan tujuan pembelajaran khusus yaitu: mahasiswa mempunyai kemampuan HOT yang ditunjukkan oleh: (1) mampu menyelesaikan permasalahan Aljabar dengan menerapkan beberapa konsep Aljabar dan ajaran $3 \mathrm{~N}$ secara mandiri, bermutu dan terukur; (2) mampu memilih strategi yang tepat dalam menyelesaikan permasalahan Aljabar dan dapat mempertanggungjawabkan hasil penerapan strategi. Kedua tujuan pembelajaran khusus tersebut dicapai dengan memanfaatkan Bank Soal HOTS Berbasis 3N sebagai bahan ajar sekaligus media pembiasaan dalam menyelesaikan permasalahan non rutin

\section{PENUTUP}

Masalah yang ditemukan dalam analisi awal-akhir dan karakteristik mahasiswa pada studi pendahuluan penelitian pengembangan ini meliputi:
(1) pembelajaran Aljabar masih berpusat pada dosen dan mahasiswa kesulitan menyelesaikan soal non-rutin, (2) hanya terdapat $1,59 \%$ mahasiswa yang menerapkan tahap memeriksa kebenaran solusi dalam pemecahan masalah HOT. Analisis konsep dan tugas menghasilkan 2 CPMK yaitu: (1) Mampu menyelesaikan permasalahan Aljabar dengan menerapkan beberapa konsep Aljabar dan ajaran 3N secara mandiri, bermutu dan terukur, (2) Mampu memilih strategi yang tepat dalam menyelesaikan permasalahan Aljabar dan dapat mempertanggungjawabkan hasil penerapan strategi tersebut. Berdasarkan beberapa hasil tersebut, disusun tujuan pembelajaran khusus yaitu mahasiswa mempunyai kemampuan HOT yang ditunjukkan oleh: (1) mampu menyelesaikan permasalahan Aljabar dengan menerapkan beberapa konsep Aljabar dan ajaran $3 \mathrm{~N}$ secara mandiri, bermutu dan terukur, (2) mampu memilih strategi yang tepat dalam menyelesaikan permasalahan Aljabar dan dapat mempertanggungjawabkan hasil penerapan strategi. Hasil penelitian ini selanjutnya akan menjadi acuan dalam penelitian selanjutnya yaitu tahap perancangan Bank Soal HOTS Berbasis $3 \mathrm{~N}$ pada Materi Aljabar.

\section{DAFTAR PUSTAKA}

Adelman, C. (2006). The toolbox revisited: Paths to degree completion from high school through college. US Department of Education.

Andriani, P. (2015). Penalaran Aljabar dalam Pembelajaran Matematika. Beta: Jurnal Tadris Matematika, 8(1), 1-13. 
Budiati, N., Purnami, A. S., \& Agustito, D. (2018). Penerapan Konsep 3n (Niteni, Nirokke, Nambahi) dalam Pembelajaran Matematika. Prosiding Seminar Nasional Pendidikan Matematika Etnomatnesia.

Camac, K. (2018). Student-Centered Approach Vs. Teacher-Centered Approach: Which Is More Effective For A Graduate Data Analytics Course In An ELearning Environment?

Conklin, W. (2011). Higher-order thinking skills to develop 21st century learners. Teacher Created Materials.

Dr. I Wayan Widana, S.Pd., M. P. (2017). Modul Penyusunan Soal HOTS. 48.

Fan, L., \& Zhu, Y. (2007). Representation of problem-solving procedures: A comparative look at China, Singapore, and US mathematics textbooks. Educational Studies in Mathematics, 66(1), 61-75.

Gunawan, I., \& Palupi, A. R. (2016). Taksonomi Bloom-revisi ranah kognitif: kerangka landasan untuk pembelajaran, pengajaran, dan penilaian. Premiere Educandum: Jurnal Pendidikan Dasar Dan Pembelajaran, 2(02).

Hendriana, H., Rohaeti, E. E., \& Sumarmo, U. (2017). Hard skills dan soft skills matematik siswa. Bandung: Refika Aditama.

Hendriana, H., \& Soemarmo, U. (2014). Penilaian pembelajaran matematika. Bandung: Refika Aditama.

Hendriana, H., \& Soemarmo, U. (2017). Penilaian Pembelajaran Matematika Edisi Revisi.
Bandung: PT Refika Aditama.

Herbert, M. (1984). Comprehensive School Mathematics Program. Final Evaluation Report.

Herriott, S. R., \& Dunbar, S. R. (2009). Who takes college algebra? Primus, 19(1), 74-87.

Ipung Kurniawan Yunianto, I. (2014). JOGJAFORCE: Niteni, Nirokne, Nambahi Sebagai Proses Berpikir Kreatif. Jurnal Desain Komunikasi Visual, 2(2), 121-133.

Kaufmann, J. E., \& Schwitters, K. L. (2014). Algebra for college students. Nelson Education.

Liljedahl, P., Santos-Trigo, M., Malaspina, U., \& Bruder, R. (2016). Problem solving in mathematics education. Springer Nature.

Ma, X., \& Wilkins, J. L. M. (2007). Mathematics coursework regulates growth in mathematics achievement. Journal for Research in Mathematics Education, 230257.

Mahdayani, R. (2016). Analisis kesulitan siswa dalam pemecahan masalah matematika pada materi aritmatika, aljabar, statistika, dan geometri. Jurnal Pendas Mahakam, 1(1), 86-98.

Mairing, J. P. (2018). Higher Order Thinking Skills Mahasiswa Pendidikan Matematika Dalam Memecahkan Masalah Struktur Aljabar. Seminar Nasional Riset Inovatif, 6, 139-143.

Muhammad, G. M. (2017). Analisis Kemampuan Penalaran Matematis Mahasiswa pada Mata Kuliah Struktur Aljabar II (Teori Gelanggang). PRISMA, 6(1), 6678. 
Nailul, F. (2018). ᄀ Pengembangan Soal Higher Order Thinking Skills (HOTS) Pada Materi Barisan Dan Deret Bilangan Di Sma Negeri 1 Puri. Unversitas Islam Majapahit.

No, Permendikbud. (21 C.E.). Tahun 2016. Standar Isi Pendidikan Dasar Dan Menengah Yang Memuat Tentang Tingkat Kompetensi Dan Kompetensi Inti Sesuai Dengan Jenjang Dan Jenis Pendidika Tertentu.

No, Permenristekdikti. (44 C.E.). Tahun 2015 \& Lampiran. Standar Nasiona LPendidikan Tinggi.

No, Perpres. (8 C.E.). tahun 2012 tentang KKNI.

Nuriyatin, S., \& Widadah, S. (2018). Kemampuan Berpikir Tingkat Tinggi Mahasiswa Calon Guru Dalam Mengajukan Masalah Matematika Sekolah. Unisda Journal of Mathematics and Computer Science (UJMC), 4(1), 19-26.

Pasandaran, R. F. (2019). Representasi Matematika dalam Penyelesaian Masalah Non Rutin. Guru Tua: Jurnal Pendidikan Dan Pembelajaran, 2(1), 45-52.

Polly, D., Margerison, A., \& Piel, J. A. (2014). Kindergarten teachers' orientations to teacher-centered and student-centered pedagogies and their influence on their students' understanding of addition. Journal of Research in Childhood Education, 28(1), 1-17.

Prasetyo, Z. K. (2011). Pengembangan perangkat pembelajaran sains terpadu untuk meningkatkan kognitif, keterampilan proses, kreativitas serta menerapkan konsep ilmiah peserta didik SMP. Program

Pascasarjana
Universitas Negeri Yogyakarta.

Raco, J. (n.d.). Metode penelitian kualitatif: jenis, karakteristik dan keunggulannya.

Raharjo, J. F. (2017). Mengembangkan Kemampuan Berpikir Aljabar dan Kemandirian Belajar Mahasiswa melalui Pendekatan Saintifik Model PACE pada Mata Kuliah Struktur Aljabar. JIPMat, 1(2).

Resbiantoro, G., \& Nugraha, A. W. (2017). Miskonsepsi mahasiswa pada konsep dasar gaya dan gerak untuk sekolah dasar. Jurnal Pendidikan Sains (JPS), 5(2), 8087.

Riset, P. M. (n.d.). Teknologi dan Pendidikan Tinggi No. 44 Tahun 2015 tentang Standar Nasional Pendidikan Tinggi. Diakses $D i$ Http://Pasca. Unila. Ac. Id/WpContent/Uploads/2016/01/Permen ristekdikti-No-44-Tahun-2015SN-DIKTI Pdf Pada, 5.

Sariningsih, R., \& Kadarisma, G. (2016). Meningkatkan Kemampuan Berpikir Kreatif Matematis dan Kemandirian Belajar Siswa SMP Melalui Pendekatan Saintifik berbasis Etnomatematika. P2M STKIP Siliwangi, 3(1), 53-56.

Simanjuntak, E. (n.d.). Sikap mahasiswa terhadap Pembelajaran Aljabar Linier Elementer dengan Reciprocal Teaching. Inspiratif: Jurnal Pendidikan Matematika, 2(1).

Sulistyowati, F., Budiyono, B., \& Slamet, I. (2017). Problem Solving Reasoning and Problem Based Instruction in Geometry Learning. Journal of Physics: Conference Series, 895(1). https://doi.org/10.1088/17426596/895/1/012045 
Sulistyowati, F., Kuncoro, K. S., Setiana, D. S., \& Purwoko, R. Y. (2019). Solving high order thinking problem with a different way in trigonometry. Journal of Physics: Conference Series, 1315(1), 12001.

Sunarsi, D. (2018). Pengembangan Sumber Daya Manusia Strategik \& Karakterisrik Sistem Pendukungnya: Sebuah Tinjauan. Jurnal Ilmiah MEA (Manajemen, Ekonomi, \& Akuntansi), 2(3), 178194.

Thiagarajan, S. (1974). Instructional development for training teachers of exceptional children: A sourcebook.

Utari, S., Heris, H., Ahmad, A., \& Anik, Y. (2019). Tes dan Skala Matematika Bernuansa High Order Thinking Skills. PT Refika Aditama.

Wahyuni, D. (2017). Pengintegrasian Sastra pada Pembelajaran Bahasa Melalui Pendekatan Ilmiah. Madah: Jurnal Bahasa Dan Sastra, 5(1), 67-80.

Waluyo, M., \& Sari, C. K. (2017). Kesalahan Penalaran Dalam Pembuktian Masalah Struktur
Aljabar. JIPMat, 2(2).

Werdiningsih, C. E. (2019). Pengaruh Kemandirian Belajar Dan Berpikir Lateral Terhadap Kemampuan Pemecahan Masalah Matematika Pada Mata Kuliah Struktur Aljabar. Prosiding Seminar Nasional Pendidikan KALUNI, 2, 222-230.

https://doi.org/10.30998/prokaluni .v2i0.65

Woodward, E. (1980). CSMP: A New Alternative in Elementary School Mathematics. The Arithmetic Teacher, 27(6), 20-26.

Yulianti, S. D., Djatmika, E. T., \& Santoso, A. (2017). Pendidikan karakter kerja sama dalam pembelajaran siswa sekolah dasar pada kurikulum 2013. Jurnal Teori Dan Praksis Pembelajaran IPS, 1(1), 33-38. 